\title{
Substrate and p-layer effects on polymorphous silicon solar cells
}

\author{
S.N. Abolmasov ${ }^{1, a}$, H. Woo ${ }^{1}$, R. Planques ${ }^{1}$, J. Holovský ${ }^{2}$, E.V. Johnson ${ }^{1}$, A. Purkrt ${ }^{2}$, and P. Roca i Cabarrocas ${ }^{1}$ \\ 1 LPICM, CNRS, École Polytechnique, 91128 Palaiseau, France \\ 2 Institute of Physics, ASCR v.v.i. Cukrovarnická, Prague, Czech Republic
}

Received: 30 July 2013 / Accepted: 11 June 2014

Published online: 16 July 2014

(c) Abolmasov et al., published by EDP Sciences, 2014

\begin{abstract}
The influence of textured transparent conducting oxide (TCO) substrate and $p$-layer on the performance of single-junction hydrogenated polymorphous silicon ( $p m-\mathrm{Si}: \mathrm{H})$ solar cells has been addressed. Comparative studies were performed using $p$ - $i$ - $n$ devices with identical $i / n$-layers and back reflectors fabricated on textured Asahi U-type fluorine-doped $\mathrm{SnO}_{2}$, low-pressure chemical vapor deposited (LPCVD) boron-doped $\mathrm{ZnO}$ and sputtered/etched aluminum-doped $\mathrm{ZnO}$ substrates. The $p$-layers were hydrogenated amorphous silicon carbon and microcrystalline silicon oxide. As expected, the type of TCO and $p$-layer both have a great influence on the initial conversion efficiency of the solar cells. However they have no effect on the defect density of the $p m$-Si:H absorber layer.
\end{abstract}

\section{Introduction}

General trends in thin film silicon $(\mathrm{Si})$ photovoltaics are the reduction of the production costs and improvement of the conversion efficiency. The state of the art in thin film silicon solar cells utilizes tandem structures which pair a hydrogenated amorphous $\mathrm{Si}(a-\mathrm{Si}: \mathrm{H})$ top cell with a hydrogenated microcrystalline $\mathrm{Si}(\mu c-\mathrm{Si}: \mathrm{H})$ bottom cell. The efficiency and cost of these tandem cells are mainly limited by the light-induced degradation of $a$ $\mathrm{Si}: \mathrm{H}$ and the low absorption coefficient/deposition rate of $\mu c$-Si:H, respectively [1]. Therefore, there has been considerable interest recently in wide band gap nanostructured Si materials which may offer better performance/stability to the top cell and allow reducing the thickness of the bottom cell using enhanced light trapping techniques. These nanostructured Si materials mainly include hydrogenated amorphous and microcrystalline silicon oxide ( $a$ - and $\mu c$ $\mathrm{SiO}: \mathrm{H})[2-8]$, protocrystalline $(p c-\mathrm{Si}: \mathrm{H})[9]$ and polymorphous ( $p m-\mathrm{Si}: \mathrm{H})$ silicon [10] that could be used as alternatives to standard doped and absorber layers, respectively. On the other hand, the light trapping is mainly realized by texturing of transparent conductive oxide (TCO) layers on glass substrates [11]. However, this approach tends to deteriorate the electrical parameters of the cells with both $a$ - and $\mu c-\mathrm{Si}: \mathrm{H}$ absorber layers $[12,13]$. The goal of this study is to evaluate the performance of single-junction $(p-i-n) p m-\mathrm{Si}: \mathrm{H}$ solar cells on different textured TCO substrates which also incorporate $p$-type silicon oxide films as the window layer. To examine the substrate and $p$-layer

${ }^{a}$ e-mail: sergey.abolmasov@polytechnique.edu effects on $p m$-Si:H solar cell performance, the cells were fabricated with the same $i$ - and $n$-layers.

\section{Experimental}

Silicon films were deposited in a $13.56 \mathrm{MHz}$ radiofrequency plasma enhanced chemical vapor deposition (RF-PECVD) system, consisting of a single vacuum vessel containing three independent plasma chambers [14]. Mixtures of $\mathrm{H}_{2} / \mathrm{SiH}_{4} / \mathrm{CO}_{2} / \mathrm{B}\left(\mathrm{CH}_{3}\right)_{3}, \mathrm{H}_{2} / \mathrm{SiH}_{4}$ and $\mathrm{H}_{2} / \mathrm{SiH}_{4} / \mathrm{PH}_{3}$ were used as source gases for the growth of $p$-type $a$-SiO:H, intrinsic $p m$-Si:H and $n$-type $a-\mathrm{Si}: \mathrm{H}$ or $\mu c-\mathrm{Si}: \mathrm{H}$, respectively. The $p-i-n$ devices were fabricated on textured Asahi U-type fluorine-doped tin oxide $\left(\mathrm{SnO}_{2}: \mathrm{F}\right)$, low-pressure chemical vapor deposited (LPCVD) boron-doped ( $\mathrm{ZnO}: \mathrm{B}) \mathrm{ZnO}$ (type A), and $\mathrm{RF}$ sputtered and etched (sp-e) aluminum-doped zinc oxide ( $\mathrm{ZnO}: \mathrm{Al}$ ) coated glass substrates (1 mm thick). Details on TCO deposition processes along with TCO characteristics can be found in references [15-17]. Aluminum back contacts were deposited by thermal evaporation. Sputtered $\mathrm{ZnO} / \mathrm{Ag}$ stacks were also used as back reflectors to enhance the light trapping from the back side of the device. The cells areas were defined by using a shadow mask $\left(0.126 \mathrm{~cm}^{2}\right)$. Fourier transform photocurrent spectroscopy (FTPS) [18] was used to determine the effect of the TCO substrate on the absorption coefficient $(\alpha)$ and defect density of $p m-\mathrm{Si}: \mathrm{H}$ in the cells. Dark conductivity $\left(\sigma_{d}\right)$ of $p$-type silicon oxide on Corning 7059 glass was measured using a coplanar Al electrode configuration. The optical properties and thickness of the films were measured 

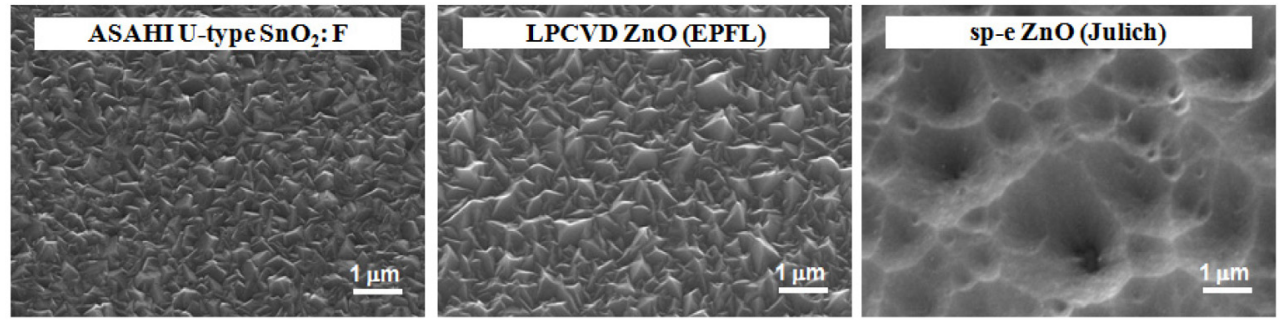

Fig. 1. Scanning electron microscope (SEM) images of textured TCO substrates used in this study (top view under an angle of $\left.30^{\circ}\right)$.

with UV-visible spectroscopic ellipsometry (SE). The $J$ $V$-characteristics and external quantum efficiency (EQE) of the solar cells were measured under 1 sun illumination at $25^{\circ} \mathrm{C}$. A 1 -mm-diameter orifice was used for the EQE and reflectivity measurements. Most results were obtained on cells in the annealed state $\left(40 \mathrm{~min}\right.$ at $\left.150{ }^{\circ} \mathrm{C}\right)$. Accelerated light-induced degradation (LID) tests were performed at approximately 2 suns in a home-made LID system using Oriel Apex illuminator (Model 71223) with a quartz tungsten halogen lamp. The cell temperature was kept at $50{ }^{\circ} \mathrm{C}$. In this case, the $J$ - $V$-characteristics were measured in situ using the same lamp and a neutral density filter, resulting in a light exposure equivalent to 1 sun.

\section{Results and discussion}

The surface morphologies of the textured TCO substrates used in this study are shown in Figure 1. It is obvious that the front TCO layer has to exhibit high transparency in the useful spectrum range and a sufficient conductivity to limit the series resistance of the cell. However, it must also have sufficient surface roughness to optimize the light confinement [11]. It can be seen in Figure 1 that there is a significant difference in the surface roughness of the three TCO layers. Both $\mathrm{SnO}_{2}$ and LPCVD ZnO have pyramidal features with sizes below $500 \mathrm{~nm}$ that are well suited for effective light trapping in $a$-Si:H solar cells. On the other hand, sp-e $\mathrm{ZnO}$ has much smoother surface with lateral features that are more than $1 \mu \mathrm{m}$ in size and therefore is more suited for the use in $\mu c-\mathrm{Si}: \mathrm{H}$ solar cells. Because the properties of TCO may also vary significantly, appropriate window $p$-layers should be developed. For example, it is well known that a textured $\mathrm{SnO}_{2}$ front contact is susceptible to reduction by hydrogen $[19,20]$. Therefore, $\mathrm{ZnO}$ has recently been investigated as an alternative that is both resistant to hydrogen plasma induced darkening and has higher transmission. However, fabrication of $p-i-n$ devices on $\mathrm{ZnO}$ results in a lower fill factor $(F F)$, which is believed to be due to a rectifying contact that is formed between the $p$-type $a$-Si:H and the $n$-type $\mathrm{ZnO}$ layer [21]. There have been numerous attempts to overcome this problem [22-25], but there is still lack of a complete understanding of the phenomenon. The most efficient way to overcome the problem is to use an ultrathin $\mu c-\mathrm{Si}: \mathrm{H}$ or silicon oxide $(\mu c-\mathrm{SiO}: \mathrm{H}) p$-layer, which is more conducting than a hydrogenated amorphous silicon carbide $(a-\mathrm{SiC}: \mathrm{H})$ p-layer $[2,4,5]$.

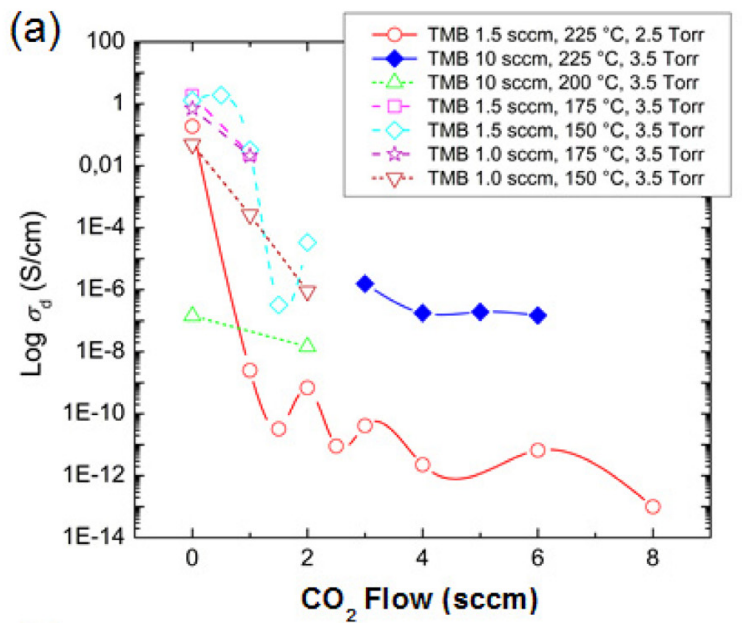

(b)

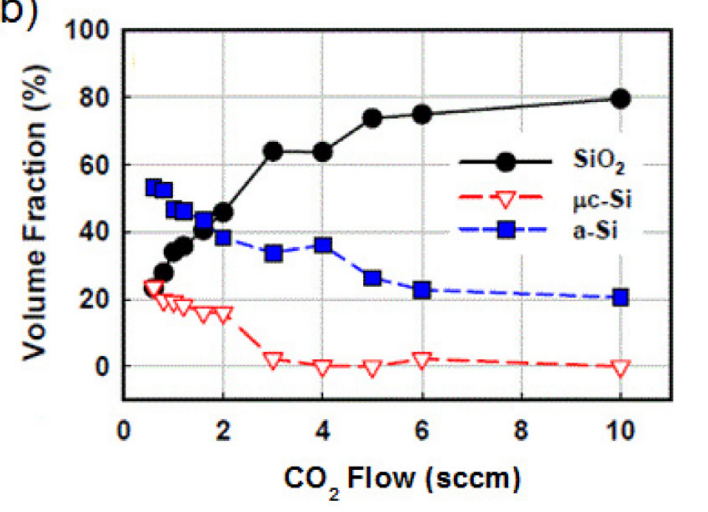

Fig. 2. (a) Dark conductivity (at room temperature) of $p$-type silicon oxide thin films as a function of $\mathrm{CO}_{2}$ flow rate (the films were grown on Corning glass at $\mathrm{H}_{2}(500 \mathrm{sccm}) / \mathrm{SiH}_{4}(10 \mathrm{sccm})$ $=50$ and with $2 \% \mathrm{~B}\left(\mathrm{CH}_{3}\right)_{3}$ in $\left.\mathrm{H}_{2}\right)$ and (b) evolution of $\mathrm{SiO}_{2}$, $a-\mathrm{Si}$ and $\mu c-\mathrm{Si}$ volume fractions of optimized $\mu c-\mathrm{SiO}: \mathrm{H} p$-layer with increasing $\mathrm{CO}_{2}$ flow rate, as deduced from the BEMA modeling.

Like the TCO layer, the window layer should also exhibit high transparency and sufficient conductivity. For the silicon oxide $p$-layer deposition, a wide range of deposition parameters such as RF power, inter-electrode distance, substrate temperature, gas composition, pressure and flow were optimized. It turns out that lowering the $\mathrm{CO}_{2}$ and $\mathrm{B}\left(\mathrm{CH}_{3}\right)_{3}$ concentration favors the growth of conductive silicon oxide $p$-layers, as shown in Figure $2 \mathrm{a}$. The results of $\mathrm{SE}$ measurements/modeling for optimized $p$ layers grown at $p=3.5$ Torr, $T=175{ }^{\circ} \mathrm{C}$ and a TMB 
S.N. Abolmasov et al.: Substrate and p-layer effects on polymorphous silicon solar cells

Table 1. Initial photovoltaic parameters of $p m-\mathrm{Si}: \mathrm{H} p$ - $i-n$ devices fabricated on three different TCO substrates along with the absorption coefficient and the Urbach energy of their intrinsic $p m$-Si:H layer. All the cells incorporate the same $i-p m$-Si:H $(300 \mathrm{~nm})$ and $n-a-\mathrm{Si}: \mathrm{H}$ layers and evaporated Al back contacts.

\begin{tabular}{cccccccc}
\hline Sample \# & $\begin{array}{c}\mathrm{TCO} / p \text {-layer } \\
\text { description }\end{array}$ & $\begin{array}{c}\alpha(1.2 \mathrm{eV}) \\
\left(\mathrm{cm}^{-1}\right)\end{array}$ & $\begin{array}{c}E_{U} \\
(\mathrm{meV})\end{array}$ & $\begin{array}{c}F F \\
(\%)\end{array}$ & $\begin{array}{c}V_{O C} \\
(\mathrm{~V})\end{array}$ & $\begin{array}{c}J_{S C} \\
\left(\mathrm{~mA} / \mathrm{cm}^{2}\right)\end{array}$ & $\begin{array}{c}\text { Eff. } \\
(\%)\end{array}$ \\
\hline 1207271 & $\begin{array}{c}\mathrm{ASAHI} \mathrm{SnO}_{2}(\mathrm{ref}) \\
a-\mathrm{SiC} p \text {-layer }\end{array}$ & $0.15 \pm 0.03$ & $39.9 \pm 2$ & 71.77 & 0.868 & 12.65 & 7.88 \\
\hline $1208071 \mathrm{I}$ & $\begin{array}{c}\mathrm{LPCVD} \mathrm{ZnO} \\
\mu c-\mathrm{SiO}_{x} p \text {-layer \#1 }\end{array}$ & $0.18 \pm 0.02$ & $39.6 \pm 0.8$ & 69.71 & 0.853 & 11.19 & 6.65 \\
\hline $1208071 \mathrm{~J}$ & $\begin{array}{c}\text { sp-e ZnO } \\
\mu c-\mathrm{SiO}_{x} p \text {-layer \#1 }\end{array}$ & $0.13 \pm 0.05$ & $37.8 \pm 1.5$ & 66.23 & 0.881 & 10.08 & 5.88 \\
\hline
\end{tabular}

Table 2. Initial photovoltaic parameters of $p m-\mathrm{Si}: \mathrm{H} p-i-n$ devices fabricated on three different TCO substrates. All the cells incorporate the same $p-\mu c-\mathrm{SiO}: \mathrm{H}, i$ - $p m$ - Si:H $(250 \mathrm{~nm})$ and $n-\mu c$-Si:H layers and sputtered $\mathrm{ZnO}-\mathrm{Ag}$ back contacts.

\begin{tabular}{cccccc}
\hline Sample \# & $\begin{array}{c}\mathrm{TCO} / p \text {-layer } \\
\text { description }\end{array}$ & $\begin{array}{c}F F \\
(\%)\end{array}$ & $\begin{array}{c}V_{O C} \\
(\mathrm{~V})\end{array}$ & $\begin{array}{c}J_{S C} \\
\left(\mathrm{~mA} / \mathrm{cm}^{2}\right)\end{array}$ & $\begin{array}{c}\text { Eff. } \\
(\%)\end{array}$ \\
\hline $1301245 \mathrm{I}$ & $\begin{array}{c}\mathrm{LPCVD} \mathrm{ZnO} \\
\mu c-\mathrm{SiO}_{x} \text { p-layer \#2 }\end{array}$ & 68.54 & 0.903 & 14.83 & 9.2 \\
\hline $1301245 \mathrm{~J}$ & $\begin{array}{c}\text { sp-e ZnO } \\
\mu c-\mathrm{SiO}_{x} \text { p-layer \#2 }\end{array}$ & 61.09 & 0.918 & 13.54 & 7.6 \\
\hline $1301245 \mathrm{~A}$ & $\begin{array}{c}\mathrm{ASAHI} \mathrm{SnO}_{2} \\
\mu c-\mathrm{SiO}_{x} \text { p-layer \#2 }\end{array}$ & 55.27 & 0.793 & 13.69 & 6.0 \\
\hline
\end{tabular}

flow rate of $1.5 \mathrm{sccm}$ indicate that the optical band-gap energy $\left(E_{g}\right)$ of these thin films can be increased from 1.95 to $2.8 \mathrm{eV}$ by increasing the $\mathrm{CO}_{2}$ flow rate from 1 to $10 \mathrm{sccm}$. The increase in $E_{g}$ is mainly due to an increase in the oxygen concentration, whereas the conductivity of these films is controlled by their $\mu c$-Si fraction as determined from the modeling of the spectroscopic ellipsometry data. The measured spectra were modeled using the Bruggeman's effective medium approximation (BEMA) [26], in which the silicon oxide material was considered as being a physical combination of three distinct phases formed by $\mathrm{SiO}_{2}, a-\mathrm{Si}$ and $\mu c$-Si. Figure $2 \mathrm{~b}$ shows that the $\mu c$-Si fraction in our optimized silicon oxide $p$-layer, according to the BEMA model, does not exceed $20 \%$ and sharply decreases with increasing the $\mathrm{CO}_{2}$ mass flow rate above $2 \mathrm{sccm}$ [27]. In our case the silicon oxide $p$-layer was grown at a $\mathrm{CO}_{2}$ mass flow rate of $1 \mathrm{sccm}$. Such a layer has a $19 \% \mu c$-Si fraction and thereby referred to as $\mu c-\mathrm{SiO}: \mathrm{H}$ in the paper.

In the first series of experiments, the $\mathrm{TCO} / p$-layer and $p / i$ interface regions of the cells deposited on the three types of TCO substrates were systematically improved by introducing thin buffer layers. By optimizing the doping profile (by adding one or more layers grown with different gas composition) and thickness of the window $p$-layer, the cell current was improved while maintaining relatively high $F F$ and open circuit voltage $\left(V_{O C}\right)$. Typically the $p$-layer was a 3 -layer-stack consisting of an ultra-thin $\mu c$ $\mathrm{Si}: \mathrm{H}$, a heavily doped $\mu c-\mathrm{SiO}: \mathrm{H}$ and a lightly doped $\mu c$ $\mathrm{SiO}: \mathrm{H}$ layer. Such multilayer structure provides a wider process window, enabling the use of much thinner window p-layer. Consequently, short-circuit current $J_{S C}$ and $V_{O C}$ were enhanced with only a small drop in FF. Since the growth of both $\mu c-\mathrm{SiO}: \mathrm{H}$ and $p m-\mathrm{Si}: \mathrm{H}$ requires a hydrogen rich plasma, an $a$-SiC:H $p$-layer was used in the case of
$\mathrm{SnO}_{2}$ substrate and served as a reference. Moreover, FTPS was used to check the quality of the $p m-\mathrm{Si}: \mathrm{H}$ in the cells grown on the three TCO substrates. Interestingly enough, the FTPS results, obtained for the cells with a $300 \mathrm{~nm}$ thick intrinsic layer and an $a$-Si:H $n$-layer, shown in Figure 3 indicate very similar $\mathrm{pm}$-Si:H material properties in the cells with a defect density below $5 \times 10^{15} \mathrm{~cm}^{-3}$ and Urbach energy about $40 \mathrm{meV}$. This contrasts with quite different values for the solar cell parameters summarized in Table 1, which did show a strong dependence on the TCO and $p$-layer type, thus suggesting that the surface roughness as well as the $\mathrm{TCO} / p$-layer and $p / i$ interface regions play very important roles in determining the overall cell performance. Similar results have been reported for $\mu c$-Si:H $p-i-n$ devices and it was also demonstrated that the FTPS method is sensitive to bulk material properties but not to local shunts induced by TCO morphology [28].

Further optimization of the $\mu c-\mathrm{SiO}: \mathrm{H} p$-layer $/ i$ interface and introduction of $\mathrm{ZnO} / \mathrm{Ag}$ back contacts along with a $\mu c$-Si:H $n$-layer, however, resulted in great enhancement of $J_{S C}$ and $V_{O C}$ in the cells on $\mathrm{ZnO}$ substrates, as can be seen in Table 2. Among the three different TCO substrates, sp-e $\mathrm{ZnO}$ showed the highest $V_{O C} \sim 0.92 \mathrm{~V}$, whereas LPCVD ZnO led to the highest $J_{S C} \sim 14.8 \mathrm{~mA} / \mathrm{cm}^{2}$ for the same $p-i-n /$ metal contact configuration. These two facts could be related directly to the TCO surface morphology: a smooth surface has smaller number of defects than a rough one, simply because of the difference in the surface area, resulting in higher $V_{O C}$. On the contrary, a rough surface results in light scattering and, in turn, in better light trapping. The use of the same $\mu c-\mathrm{SiO}: \mathrm{H}$-layer on $\mathrm{SnO}_{2}$ substrates, however, resulted in a deterioration of all solar cell parameters due to hydrogen plasma induced reduction of $\mathrm{SnO}_{2}$, as mentioned above. Figure 4 shows a comparison 


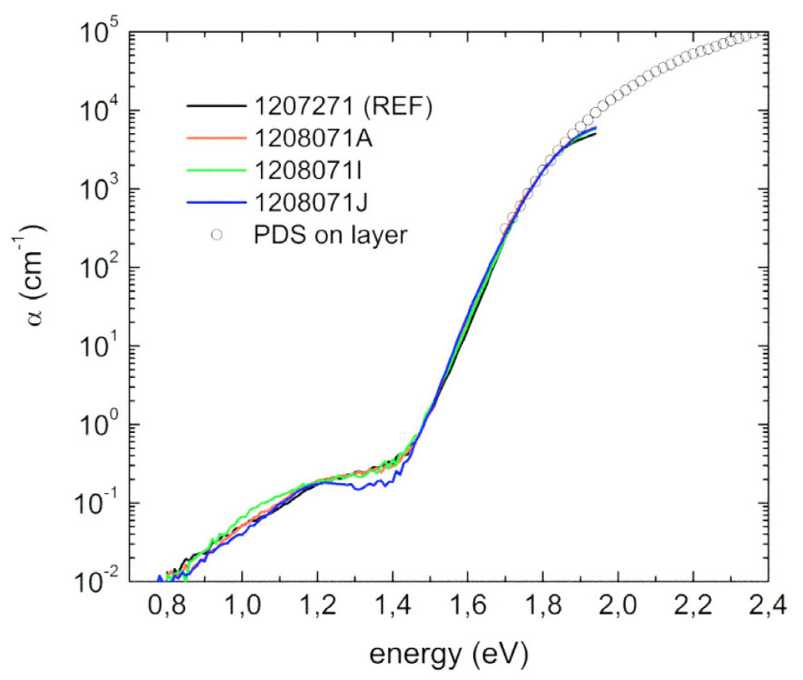

Fig. 3. Absorption coefficient of $p m-\mathrm{Si}: \mathrm{H}$ absorber layer in $p-i-n$ devices fabricated on Asahi $\mathrm{SnO}_{2}$, LPCVD ZnO and sp-e $\mathrm{ZnO}$ substrates versus photon energy measured by FTPS. The absolute scaling is made relative to $i$-layer on Corning glass measured by photothermal deflection spectroscopy (PDS).

of EQE and reflectivity curves of the three $p$ - $i$ - $n$ devices with a $250 \mathrm{~nm}$ thick $p m$-Si:H layer, indicating excellent spectral response in the blue part of the spectrum for the $p$ - $i$ - $n$ device on LPCVD $\mathrm{ZnO}$, thanks to our newly developed $\mu c$-SiO:H $p$-layer. One can see (Fig. $4 \mathrm{~b}$ ) that the $p-i-n$ on $\mathrm{SnO}_{2}$ has higher reflectivity due to $\mathrm{SnO}_{2}$ reduction by hydrogen, as mentioned above. Note that the highest $J_{S C}$ value for $\mathrm{LPCVD} \mathrm{ZnO}$ was also confirmed independently by EQE measurements at EPFL and PTB. Nevertheless, this value is still below that $\left(16.75 \mathrm{~mA} / \mathrm{cm}^{2}\right)$ obtained in the champion $p$ - $i$ - $n$ device with an a-Si:H absorber layer of the same thickness $(250 \mathrm{~nm})$ and Oerlikon LPCVD $\mathrm{ZnO}$ (front and back contact) [29]. This is partly due to the fact that $p m-\mathrm{Si}: \mathrm{H}$ has larger optical band gap and lower optical absorption compared to $a$-Si:H. For example, $E_{04}$, defined as the energy at which the absorption coefficient is equal to $10^{4} \mathrm{~cm}^{-1}$, lies approximately in the range between $1.7-$ $1.8 \mathrm{eV}$ and $1.8-1.9 \mathrm{eV}[27,30]$ (see also Fig. 3) for $a-\mathrm{Si}: \mathrm{H}$ and $p m-\mathrm{Si}: \mathrm{H}$, respectively. It should also be mentioned that the champion a-Si:H solar cell has an anti-reflection coating and a LPCVD $\mathrm{ZnO} /$ white paint back contact.

Last but not least, it has been shown recently that the regions around the window $p$-layer could also have an influence on the stability of single-junction $p m-\mathrm{Si}: \mathrm{H}$ solar cells. In particular, localized delamination of the $\mathrm{TCO} / p$ layer interface in $\mathrm{pm}$-Si:H solar cells fabricated on textured $\mathrm{SnO}_{2}$ substrates was observed during the initial stage of light-soaking [31]. Note that $p m$-Si:H was produced in a hydrogen rich plasma and hence contains more hydrogen than standard $a$-Si:H. It was proposed in reference [31] that the light-soaking of $p m$-Si:H introduces structural changes related to the diffusion of molecular hydrogen in the material with subsequent accumulation at the $\mathrm{TCO} / p$-layer interface which finally causes localized delamination of the interface, affecting the solar cell
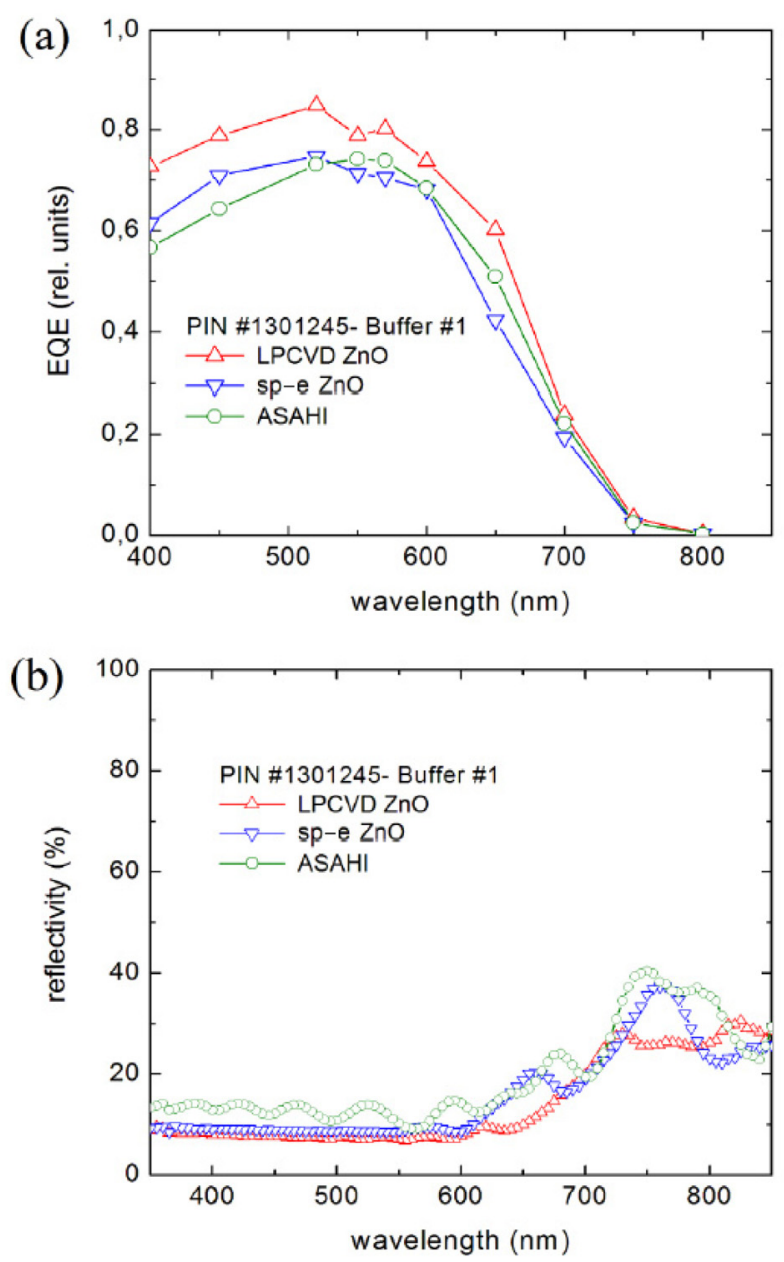

Fig. 4. External quantum efficiency of $p m-\mathrm{Si}: \mathrm{H}$ solar cells with the same $p-i-n /$ metal contact configuration fabricated on three different TCO substrates. A thin $a-\mathrm{Si}: \mathrm{H}$ buffer layer is used at the $p / i$ interface. The cells are measured in their initial state. Photovoltaic parameters of these devices are summarized in Table 2 .

parameters in an irreversible way (no recovery with thermal annealing). It is reasonable therefore to assume that the use of different TCO and/or p-layers may affect localized delamination of the interface. Note, however, that in reference [31] a xenon lamp was used to perform the light-soaking. To examine the effect further we used a home-made LID system in which a halogen lamp was employed instead of Xe lamp. Using this LID system it was found that the type of $\mathrm{TCO}$ and $\mathrm{TCO} / p$-layer interface have no effect on the initial light-induced degradation dynamics of $p m$-Si:H solar cells and no irreversible behavior was observed in our solar cells. This discrepancy is most likely due to fact that the two lamps mentioned above have very different spectral compositions: quartz tungsten halogen lamps have the spectrum with a broad maximum around $800 \mathrm{~nm}$ and a sharp decrease between 500 and $350 \mathrm{~nm}$, whereas Oriel Apex Xe lamps have an almost flat maximum in the range $350-800 \mathrm{~nm}$ [32]. Note that the maximum of solar radiation spectrum (AM1.5) lies in the 


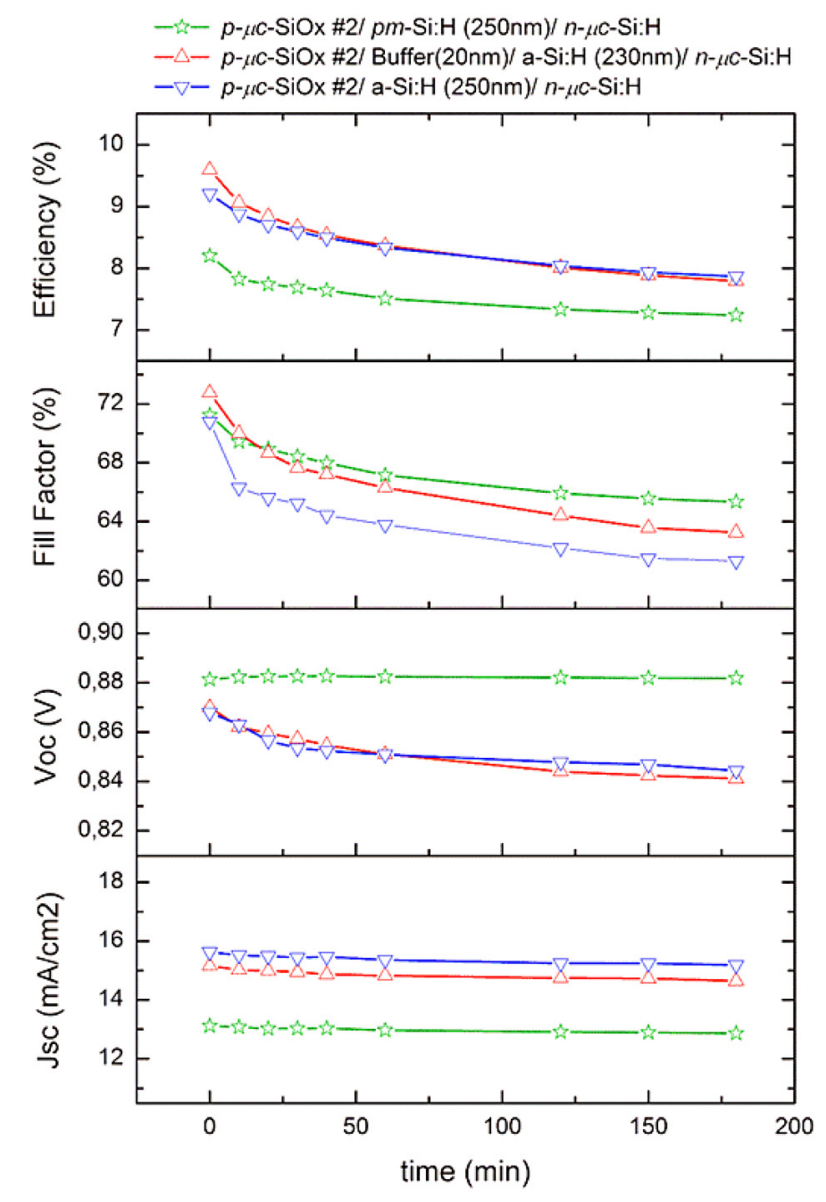

Fig. 5. Evolution of photovoltaic parameters of three different $p-i-n$ solar cells during the light-soaking under a halogen lamp illumination at 2 suns. All three cells are fabricated on LPCVD $\mathrm{ZnO}$ using sputtered $\mathrm{ZnO}-\mathrm{Ag}$ back contacts; their $p-i-n$ structures are shown at the top of graph. Note that the $J$ - $V$-characteristics are measured using the same halogen lamp at 1 sun and $50{ }^{\circ} \mathrm{C}$.

range of 500-600 $\mathrm{nm}$. Taking into account the fact that $\mathrm{SnO}_{2}$ substrates are quite transparent to the blue light it is likely that a long exposure of $p-i-n$ devices on their basis using a Xe lamp can result in severe damage of the region near the $p / i$ interface.

Because the state-of-the-art tandem silicon solar cells incorporate $a-\mathrm{Si}: \mathrm{H}$ top cells it is interesting to make a direct comparison of the LID dynamics in $a$-Si:H and pm-Si:H cells with the same thickness of intrinsic layers. Figure 5 shows such a comparison including an $a$-Si:H solar cell with a thin $(20 \mathrm{~nm}) \mathrm{pm}$-Si:H buffer layer. It is seen that degradation of $J_{S C}$ is negligibly small for the three cells with the initial $J_{S C}$ values controlled by $i$-layer band gap while most of degradation is caused by a substantial decrease in $F F$ - a common drawback among $a$-Si:H $p-i-n$ devices $[33,34]$. The decrease in $F F$ is however more severe for $a$-Si:H cell than for $p m-\mathrm{Si}: \mathrm{H}$ cell. Even though the insertion of a thin $p m$-Si:H buffer layer can improve the initial FF and conversion efficiency of a-Si:H cell, it has no effect on the conversion efficiency after $1 \mathrm{~h}$ of light-soaking: the efficiency of a-Si:H cell with a $p m-\mathrm{Si}: \mathrm{H}$ buffer layer becomes equal to that of pure $a-\mathrm{Si}: \mathrm{H}$ cell. Still the $p m-\mathrm{Si}: \mathrm{H}$ cell is the one which maintains the highest $\mathrm{FF}$ value on the long run, as recently reported for light-soaking times up to $1000 \mathrm{~h}$ [35]. Another distinguished feature of solar cells with absorber layers grown at high hydrogen dilution is that $V_{O C}$ of these cells usually increases with light-soaking time [31,36], as can be seen in Figure 5 for $p m$-Si:H $p-i-n$ device. However, despite of their better stability the efficiency of $\mathrm{pm}$-Si:H solar cells is mainly limited by lower optical absorption, as shown above. Thus, realization of effective light-trapping in single-junction $\mathrm{pm}$ Si:H solar cells on textured TCO substrates is a challenging task and so far LPCVD ZnO shows the highest $J_{S C}$. Nevertheless, higher values of stabilized $F F$ and $V_{O C}$ for $p m$-Si:H material make it attractive for the use in multijunction devices, e.g. in triple junction solar cells that do not require high $J_{S C}$.

\section{Conclusions}

The effects of textured TCO substrate and $p$-layer on the performance of single-junction $(p-i-n) p m-\mathrm{Si}: \mathrm{H}$ solar cells have been evaluated. It turns out that the type of TCO and $p$-layer both have a great influence on the initial conversion efficiency of the solar cells. A $\mu c-\mathrm{SiO}: \mathrm{H} p$-layer was successfully implemented in the cells based on $\mathrm{ZnO}$ substrates, resulting in great enhancement of their performance. In particular, the cells grown on LPCVD ZnO had the highest $J_{S C}$ and initial $\eta$, whereas those on spe $\mathrm{ZnO}$ had the highest $V_{O C}$. Unlike the strong influence on the initial efficiency, the TCO type and TCO $/ p$-layer interface had no effect on the defect density of $\mathrm{pm}$-Si:H absorber layer. The obtained results allow to conclude that $p m-\mathrm{Si}: \mathrm{H}$ is more suitable for the use in multi-junction devices such as in $3 \mathrm{~J}$ solar cells rather than in single-junction devices, mainly due to its improved stability compared to $a-\mathrm{Si}: \mathrm{H}$.

This work was carried out in the framework of the FP7 project "Fast Track", funded by the EC under grant agreement No. 283501. The authors thank the Forschungszentrum Jülich and IMT's PV-lab (EPFL) for preparation of textured $\mathrm{ZnO}$ substrates. The help of Dr. Ingo Kröger (PTB, Brunswick) and Dr. Martin Foldyna (LPICM) in validation of EQE measurements is also gratefully acknowledged.

\section{References}

1. C.A. Wolden et al., J. Vac. Sci. Technol. A 29, 030801 (2010)

2. K. Schwanitz, S. Klein, T. Stolley, M. Rohde, D. Severin, R. Trassl, Sol. Energy Mater. Sol. Cells 105, 187 (2012)

3. A. Lambertz, F. Finger, B. Hollaender, J.K. Rath, R.E.I. Schropp, J. Non-Cryst. Solids 358, 1962 (2012)

4. S. Inthisang, T. Krajangsang, I.A. Yunaz, A. Yamada, M. Konagai, C.R. Wronski, Phys. Stat. Sol. C 8, 2990 (2011) 
5. P. Cuony, M. Marending, D.T.L. Alexander, M. Boccard, G. Bugnon, M. Despeisse, C. Ballif, Appl. Phys. Lett. 97, $213502(2010)$

6. A. Sarker, A.K. Barua, Jpn J. Appl. Phys. 41, 765 (2002)

7. P. Sichanurgist, T. Yoshida, Y. Ichikawa, H. Sakai, J. NonCryst. Solids 164-166, 1081 (1993)

8. H. Watanabe, K. Haga, T. Lohner, J. Non-Cryst. Solids 164-166, 1085 (1993)

9. C.R. Wronski, J.M. Pearce, R.J. Koval, A.S. Ferlauto, R.W. Collins, in World Climate and Energy Event Proceedings, Rio de Janeiro, Brazil, 2002, p. 67

10. P. Roca i Cabarrocas, Y. Djeridane, Th. Nguyen-Tran, E.V. Johnson, A. Abramov, Q. Zhang, Plasma Phys. Control. Fusion 50, 124037 (2008)

11. M. Boccard et al., IEEE J. Photovolt. 2, 229 (2012)

12. M. Despeisse, G. Bugnon, A. Feltrin, M. Stueckelberger, P. Cuony, F. Meillaud, A. Billet, C. Ballif, Appl. Phys. Lett. 96, 73507 (2010)

13. M. Python, O. Madani, D. Dominé, F. Meillaud, E. VallatSauvain, C. Ballif, Sol. Energy Mater. Sol. Cells 93, 1714 (2009)

14. P. Roca i Cabarrocas, J.B. Chevrier, J. Huc, A. Lloret, J.Y. Parey, J.P.M. Schmitt, J. Vac. Sci. Technol. A 9, 2331 (1991)

15. K. Sato, Y. Gotoh, Y. Wakayama, Y. Hayashi, K. Adachi, H. Nishimura, Reports Res. Lab. Asahi Glass Co. Ltd. 42, 129 (1999)

16. S. Faÿ, J. Steihauser, N. Oliveira, E. Vallat-Sauvain, C. Ballif, Thin Solid Films 515, 8558 (2007)

17. J. Müller, B. Rech, J. Springer, M. Vanecek, Sol. Energy 77, 917 (2004)

18. J. Holovsky, in Fourier Transforms - New Analytical Approaches and FTIR Strategies, edited by G. Nikolic (InTech, 2011), p. 257

19. H. Schade, Z.E. Smith, J.H. Thomas, A. Catalano, Thin Solid Films 117, 149 (1984)

20. S. Kumar, B. Drevillon, J. Appl. Phys. 65, 3023 (1989)
21. E. Bohmer, F. Siebke, B. Rech, C. Beneking, H. Wagner, Mater. Res. Soc. Symp. Proc. 420, 519 (1996)

22. M. Kubon, E. Boehmer, F. Siebke, B. Rech, C. Beneking, H. Wagner, Sol. Energy Mater. Sol. Cells 14-42, 485 (1996)

23. K. Minegishi, Y. Koiwai, Y. Kikuchi, K. Yano, M. Kasuga, A. Shimizu, Jpn J. Appl. Phys. Part 2 36, L1453 (1997)

24. G. Ganguly, D.E. Carlson, S.S. Hegedus, D. Ryan, R.G. Gordon, D. Pang, R.C. Reedy, Appl. Phys. Lett. 85, 479 (2004)

25. S. Baek, J.C. Lee, Y.J. Lee, S.M. Iftiquar, Y. Kim, J. Park, J. Yi, Nanoscale Res. Lett. 7, 81 (2012)

26. G.E. Gellison, in Ellipsometry Handbook, edited by H.G. Tompkins, E.A. Irene (William Andrew, Highland Mills, 2005)

27. K.H. Kim, Ph.D. thesis, École Polytechnique, 2012

28. G. Bugnon, G. Parascandolo, T. Söderström, P. Cuony, M. Despeisse, S. Hänni, J. Holovský, F. Meillaud, C. Ballif, Adv. Funct. Mater. 22, 3665 (2012)

29. S. Benagli, D. Borrello, E. Vallat-Sauvain, J. Meier, U. Kroll, J. Hötzel, J. Spitznagel, J. Steinhauser, L. Marmello, G. Monteduro, L. Castens, in Proceedings of the 24th European Photovoltaic Solar Energy Conference, Hamburg, Germany, 2009, p. 2293

30. P. Roca i Cabarrocas, A. Fontcuberta i Morral, Y. Poissant, Thin Solid Films 403-404, 39 (2002)

31. K.H. Kim, E.V. Johnson, P. Roca i Cabarrocas, Sol. Energy Mater. Sol. Cells 105, 208 (2012)

32. Newport Spectral Irradiance Data, www.newport.com

33. H. Sakai, T. Yoshida, S. Fujikake, T. Hama, Y. Ichikawa, J. Appl. Phys. 67, 3494 (1990)

34. A. Kolodziej, Opto-Electron. Rev. 12, 21 (2004)

35. K.H. Kim, S. Kasouit, E.V. Johnson, P. Roca i Cabarrocas, Sol. Energy Mater. Sol. Cells 119, 124 (2013)

36. P. Siamchai, M. Konagai, Appl. Phys. Lett. 67, 3468 (1995) 